\title{
The Investigation of the Effects of Cognitive Motivators on Brand Loyalty with Regard to Communication Commitment, Brand Satisfaction and Effective Motivators
}

\author{
Shahriar Safapour \\ Department of marketing management, College of Management, Amin University, \\ Isfahan, Iran
}

\begin{abstract}
Brand cognitive motivations are a function of tendencies and behaviors that are inherently brand-driven of trust that consumers have compared to other brands than a brand that this considered to be customer loyalty. Accordingly, the main purpose of this study is to investigate the effects of cognitive motivators on brand loyalty, taking into account communication commitment, brand satisfaction, and effective motivators. The research type is applied and the survey is collected through a correlation method. The statistical population of the research is Nivea customers of Isfahan Brand Company at City Center Mall. The research tool of the questionnaire and the size of the society is 384 people. Therefore, 384 questionnaires were distributed and 286 questionnaires were returned without loss. The data were analyzed through SPSS and Amos software. The results show that cognitive motivators in the dimensions of awareness, perceived quality, image and perceived value of brand influence on brand satisfaction and cause customer loyalty to the brand, it is suggested that companies increase attention to customer satisfaction as one of the company's missions is important and in promoting the company highlighting points directly targeting the customer satisfaction issue that will lead to customer loyalty to the brand.
\end{abstract}

Keywords: Cognitive motivators, Brand loyalty, Community commitment, Brand satisfaction, Nivea customers of Isfahan Brand Company at City Center Mall.

DOI: $10.7176 /$ RHSS/9-10-08

Publication date:May $31^{\text {st }} 2019$

\section{Introduction}

Due to the challenges in business environment, organizations are not only seeking new customers, but they have also taken the strategy of maintaining current customers and promoting their loyalty to the organization. Therefore, customers' satisfaction is not enough and marketers should provide the ground for improving customer loyalty. In such a paradigm, the goal is to establish long-term relationships with interested groups and, most importantly, with the customer, in such a way that they retain more customers. Losing more customers to ensure market share and profitability ultimately results in the long run. Different tools are used to communicate with customers and to sell products that one of these tools is a brand.

Companies with high performance in various industries are moving towards customer retention and loyalty, as most markets are in their maturity, competition is increasing, and the cost of attracting new customers has increased sharply. To this end, in order to create effective motivations in the customer, identifying the factors and drivers of brand loyalty, brand commitment, and customer loyalty to the brand is a fundamental concept that affects a variety of factors and conditions. A lot of things make the customer motivation that their impact varies on the type of business, from organization to organization, and from store to store. The exact recognition of these factors and the determination of the effectiveness of each of them in helping managers make the right decision is of great importance. On the other hand, organizational resources are limited, and if management is to design plans to protect its customers, these resources should be allocated to these limited resources, according to the factors affecting the loyalty and importance of each of these factors (Cutler, 2016; p. 81).

The health and beauty industry is one of the growing industries of the present world and Iran. Due to the increasing number of different companies and, consequently, increasing competition in the market, it is necessary to carry out various researches and obtain the results of the relations of variables that make progress in this competitive and, of course, competitive market, by adopting strategies and decisions that are better and more measured. Due to the rise of cosmetic products, without doubt, given the competitive environment that dominates the industry in the coming years to gain an appropriate position in the minds of customers so that they remain loyal to the products, customer loyalty is a hallmark of business success and cosmetics and cosmetics company, which is based on the results of the current research on the products of Nivea, has led to an increase in the introduction of this brand to customers, which is of great importance to the organization and the same managers weaknesses and strengths. Identify the organization and, in line with the promotion of marketing activities, productivity and brand loyalty to activity and planning. Therefore, the statistical society of the present study has been formed by customers of Nivea at Center brand in Isfahan. Also, given the fact that the company's brand value is the most valuable assets of any company, the more brand the consumer is in the minds of the 
consumer, the company can gain more benefits from consumers. Therefore, the main aim of this research is to answer the question of how cognitive stimulatory effects affect brand loyalty, taking into account communication commitment, brand satisfaction and effective motivators for Nivea products in City Center of Isfahan.

\section{Research Methodology}

This research is based on the purpose of the applied type and in terms of data collection method is descriptivecorrelation research. Because of the fact that new knowledge that applies a specific application to a product or process that is true, and it describes how it interprets what it describes and relates to existing situations or relationships, common beliefs, current processes, evident effects, or growing trends. Correlation also analyzes the relationship between the variables based on the purpose of the research, because there is a correlation between the changes of a variable with other variable variations.

\subsection{Statistical Society of the Research}

The statistical population is a set of individuals, components, and factors that are common in at least one attribute. (Khaki, 1388: 250). The statistical population of this research is the customers of the New City Center of Isfahan with 384 people in the winter of 2018.

\subsection{Statistical Samples and Sampling Methods}

A statistical sample is a collection of signs that are selected from one part, a group, or a larger community, so that the set represents the quality and characteristics of that part, group, or larger community (Khaki, 2009: 250). The statistical population of this research is the customers of the New City Center of Isfahan with 384 people. Due to limited sample size, census was used so 384 questionnaires were distributed and 286 questionnaires returned without loss.

\subsection{Method and tools for data collection}

Data collection tools are scales that the researcher can collect, record and quantify their required information (Hafez Nia, 1393: 171). To carry out any kind of study, data are collected and tested using hypotheses. Data gathering method is a field and data collection tool is a questionnaire in this research. Data gathering tool was a researcher made questionnaire:

The questionnaire questions are as follows:

Table 3.1 Questions for the questionnaire broken down into each variable

\begin{tabular}{|l|l|}
\hline Question Quantity & Dimension \\
\hline $8-1$ & Brand awareness \\
\hline $16-9$ & Perceived quality \\
\hline $24-17$ & Brand image \\
\hline $33-25$ & Perceived value \\
\hline $40-34$ & Brand Enjoyment \\
\hline $50-41$ & Excitement \\
\hline $58-51$ & Satisfaction Brand \\
\hline $65-59$ & Communication commitment \\
\hline $75-66$ & Brand Loyalty \\
\hline
\end{tabular}

\subsection{Validity and reliability of the questionnaire}

In each research, the suitability of measuring instruments is very important. Each instrument should have the necessary validity and reliability so that the researcher can collect data appropriate to the research and analyze the data, test the hypotheses and respond to the research question.

\subsubsection{Validity}

The validity of this is that the scale and content of the tool or the questions contained in the data gathering tool accurately quantify the variables and the subject of the study, that is, neither the data gathered through the surplus tool on the research need nor the part of the data required for the measurement of the variables It is not removed from the content of the tool or it shows the same reality in other ways (Hafez Nia, 1393: 182). In this research, formal validity was used to make the questionnaire more reliable. Thus, the study of theoretical foundations, researches and specialized books in the field of research, as well as the views of a group of experts and professors have been used. Also, the convergence and divergence validity of the questionnaires is calculated in the fourth chapter.

\subsubsection{Reliability}

The purpose is to use the measurements in a short interval of several times and to give a group of individuals the 
results are close to each other. To measure the reliability of the index we call the coefficient of reliability, and its size is usually between zero and one. The zero coefficient represents the instability and the coefficient of reliability of one, is a complete stability assertion (Khaki, 2009: 245). In order to calculate the reliability coefficient in this study, the Cronbach alpha coefficient is used. In this method, if the alpha coefficient is more than 70 hundredth, internal consistency reliability is acceptable (Tabibi et al, 2009: 212).

Cronbach's alpha for variables is as follows:

Table 2-2. Cronbach's Alpha Criterion Questionnaire

\begin{tabular}{|l|l|}
\hline Cronbach's alpha & Variable \\
\hline 0.862 & Brand awareness \\
\hline 0.767 & Perceived quality \\
\hline 0.777 & Brand image \\
\hline 0.845 & Perceived value \\
\hline 0.812 & Brand Enjoyment \\
\hline 0.850 & Excitement \\
\hline 0.818 & Satisfaction Brand \\
\hline 0.816 & Communication commitment \\
\hline 0.857 & Brand Loyalty \\
\hline
\end{tabular}

As shown in Table (3-3), the Cronbach's alpha for all major variables has been calculated to be high (0.7). Therefore, the reliability of data collection tools is confirmed in this study.

\subsection{Analysis of data}

The main instrument for collecting data in this research was a questionnaire and respondents answered questions based on a five-degree Likert scale. Also, descriptive and inferential statistical methods are used to analyze the data. SPSS22 and Amos software is used for data analysis.

\subsubsection{Kolmogorov-Smirnov test}

The Kolmogorov-Smirnov test was used to determine the distribution of which of the variables is normal. Kolmogorov-Smirnov test is a simple nonparametric method for determining the empirical information integrity with selected statistical distributions. The Kolmogorov-Smirnov test is a method for detecting the normal distribution of frequency observations are collected. This test is used to obtain the required authorization for regression, Pearson correlation coefficient and $\mathrm{T}$ group tests on the research variables in order to prove the normality of the information.

\subsubsection{Conformity Pattern Matching Test}

The purpose of evaluating the fit of the whole model is to determine how far the whole model is compatible with the experimental data used. There is a wide range of fitness criteria and indicators that can be used to measure the fit of the entire model. Unfortunately, none of these is superior to the rest in all respects. Because a specific fitness index varies depending on the sample size, the estimation method, the complexity of the model, the assumptions about normality, or the combination of the above conditions differently. Therefore, depending on model conditions, different people may use different indexes for fitting the model. In this section, the conceptual model of the research is mapped in the form of a path diagram and measured using different methods of fitting it. A complete model of structural equations in fact represents a mixture of path diagrams and confirmatory factor analysis. 


\section{Abstraction ladder of research variables}

Abstraction form based on brand
awareness variable

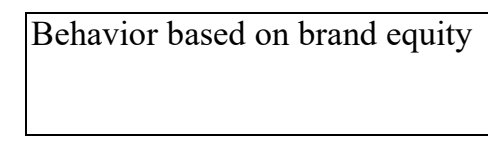

$\downarrow$

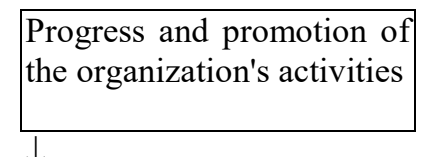

A concession is obtained from the degree of coordination between the work done with job descriptions and the acquisition of experience for the promotion of the firm's brand.

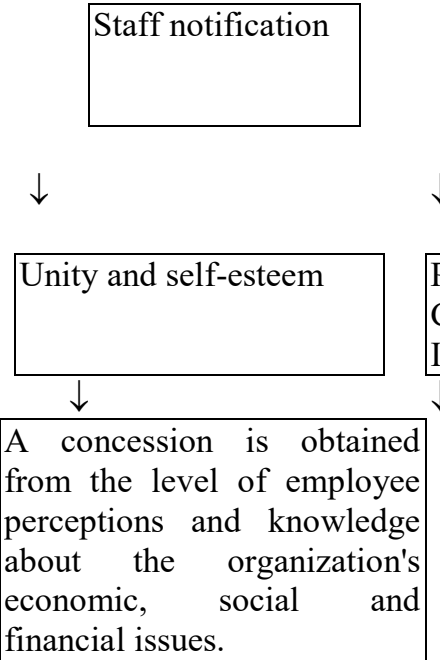

\begin{tabular}{|lr|}
\hline Exchange & knowledge \\
within & the \\
organization & \\
\hline
\end{tabular}

$\downarrow$
Proof of Knowledge, Innovation

$\downarrow$

The point is that the level of familiarity of the employees with the specialists, scholars and scientific theories related to their jobs is obtained.

\section{$\Downarrow$}

The company rewards its employees for providing brand creativity.

2. The company compares employees to their brand-based standards through collective evaluation.

3. The company adapts the behaviors to employees through educational programs.

4. When employees show behaviors that enhance brand value, the company gives them official rewards.

5. The company, using a suitable method, informs its staff about the issues that are relevant to them.

6. The company values the cooperation of individuals within the units and appreciates them.

7. Employees participate in the exchange of knowledge within the company to actively promote the brand level

8. The employees of the company are well-received for the exchange of knowledge within the company. 

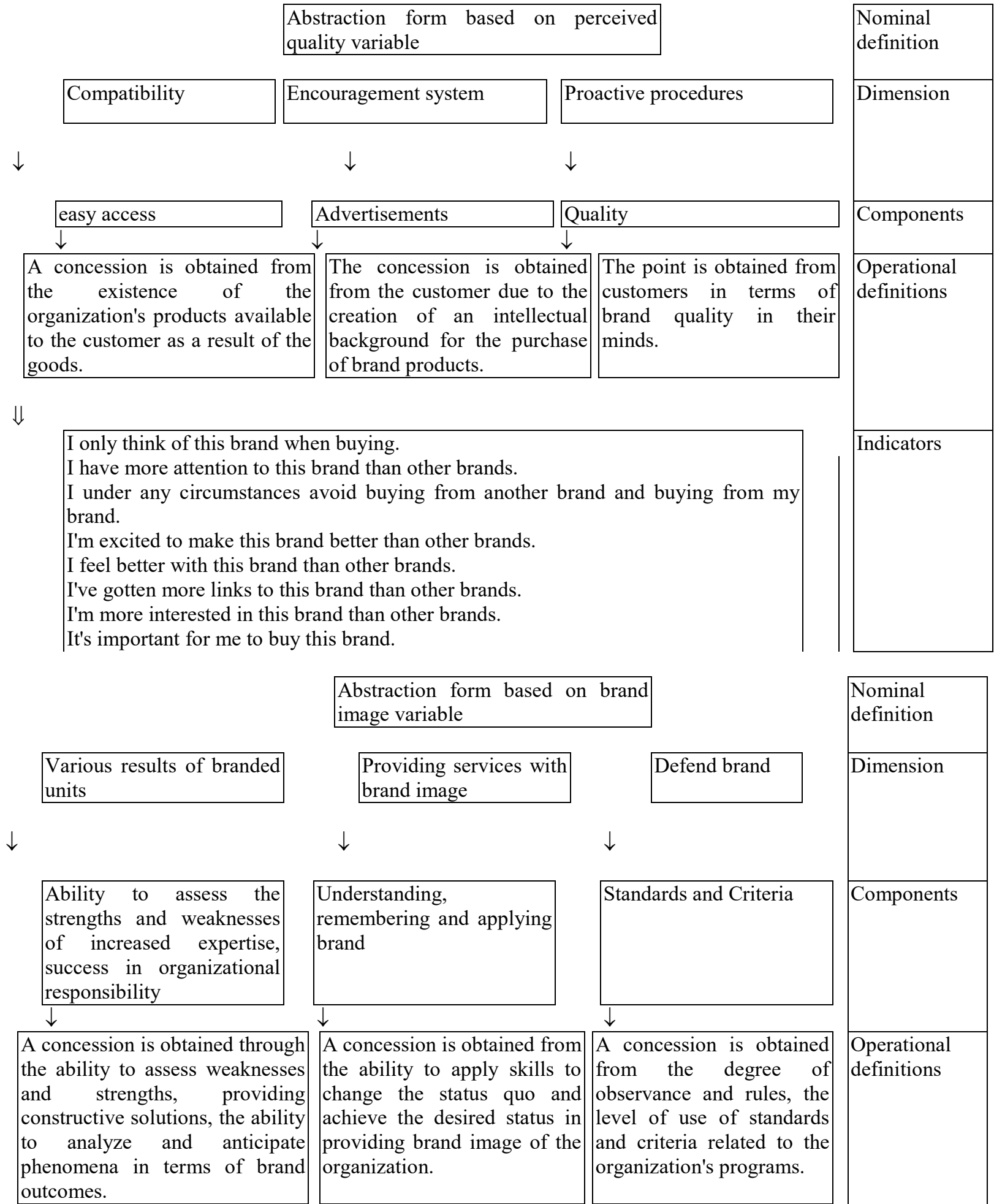

Abstraction form based on brand
image variable
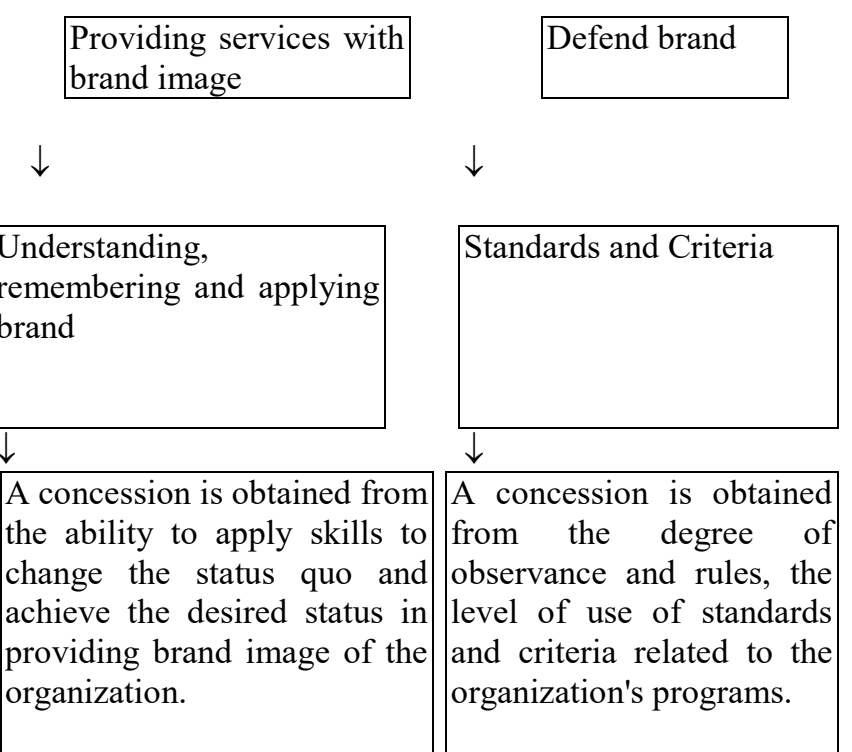

A concession is obtained from the degree of observance and rules, the level of use of standards and criteria related to the organization's programs.

$\Downarrow$

I hope that my family and acquaintances feel that my image has been incorporated into the brand image of the company.

When others blunder the brand image of the company, I defend it.

Employees successfully transfer brand value through an interactive process with customers.

Employees are hoping that customers will feel that their services are branded by the

\begin{tabular}{|l|}
\hline $\begin{array}{l}\text { Nominal } \\
\text { definition }\end{array}$ \\
\hline Dimension \\
\hline Components \\
\hline Operational \\
definitions \\
\hline
\end{tabular}


company.

It has been well-informed about improvements in the balance between work and family life.

The company has been well informed about the various work programs of the company.

A good company has been informed about the diverse results of the company's units.

Appropriate information has been provided about new and recent events in the field of issues related to the company's relationship with the outside environment.

Send feedback

History

Saved

Community

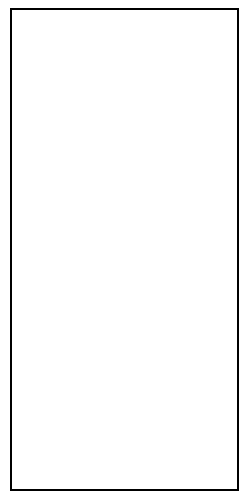

Abstraction form based on perceived value
variable

\begin{tabular}{|ll|}
\hline $\begin{array}{l}\text { Solutions to fix } \\
\text { problems }\end{array}$ & \\
& \\
\hline
\end{tabular}

$\downarrow$

Social capital, formal
and informal relations

A concession is obtained from the level of familiarity of staff with the position of the organization among competitors, books and valid articles related to the job to solve problems.

\begin{tabular}{|l|}
\hline $\begin{array}{l}\text { Implementing } \\
\text { organizational } \\
\text { procedures } \\
\text { procedures }\end{array}$ \\
\hline
\end{tabular}

$\downarrow$

\begin{tabular}{|c|}
\hline $\begin{array}{l}\text { Monitoring } \\
\text { evaluation }\end{array}$ \\
\hline$\downarrow$ \\
\hline $\begin{array}{llr}\text { A concession } & \text { is } \\
\text { obtained from making } \\
\text { decisions for the } \\
\text { deployment of human } \\
\text { resources in the } \\
\text { position associated } \\
\text { with their expertise } \\
\text { and examining the } \\
\text { strengths } \\
\text { weaknesses } \\
\text { individuals. }\end{array}$ \\
\hline
\end{tabular}

\begin{tabular}{|c|}
\hline \\
\hline$\downarrow$ \\
\hline $\begin{array}{l}\text { The privilege } \\
\text { obtained from th } \\
\text { improvement } \\
\text { operations in th } \\
\text { context } \\
\text { administrative strategi } \\
\text { issues, the training } \\
\text { staff, the improvemer } \\
\text { and improvement of th } \\
\text { organizational proces } \\
\text { in the structure of th }\end{array}$ \\
\hline
\end{tabular}
organization.
Nominal

definition

Dimension instruction of the Customer Service

$\Downarrow$

The staff are trying to help resolve organizational problems by implementing solutions

Employees follow organizational rules and procedures with conscientiousness.

Employees fail to comply with the instructions of the head of the organization.

Employees are always ready to help other employees.

Employees are willing to work with other employees to solve their problems.

Employees respond well to customer requests.

The staff constantly strives to understand customer expectations

Employees are critical in serving daily customer service.

Employees receive feedback from customer satisfaction according to their work.

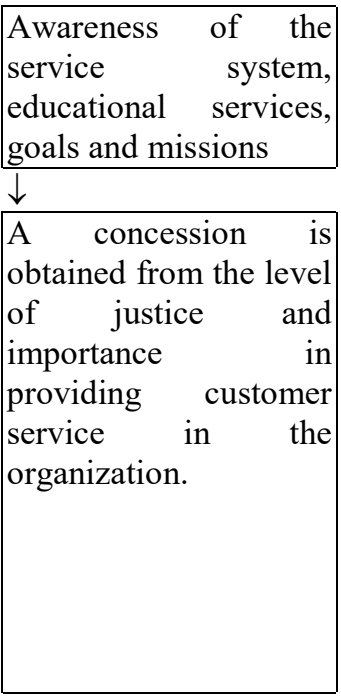

\section{Componen}

ts

.

definitions

Operation

al

ndicators 

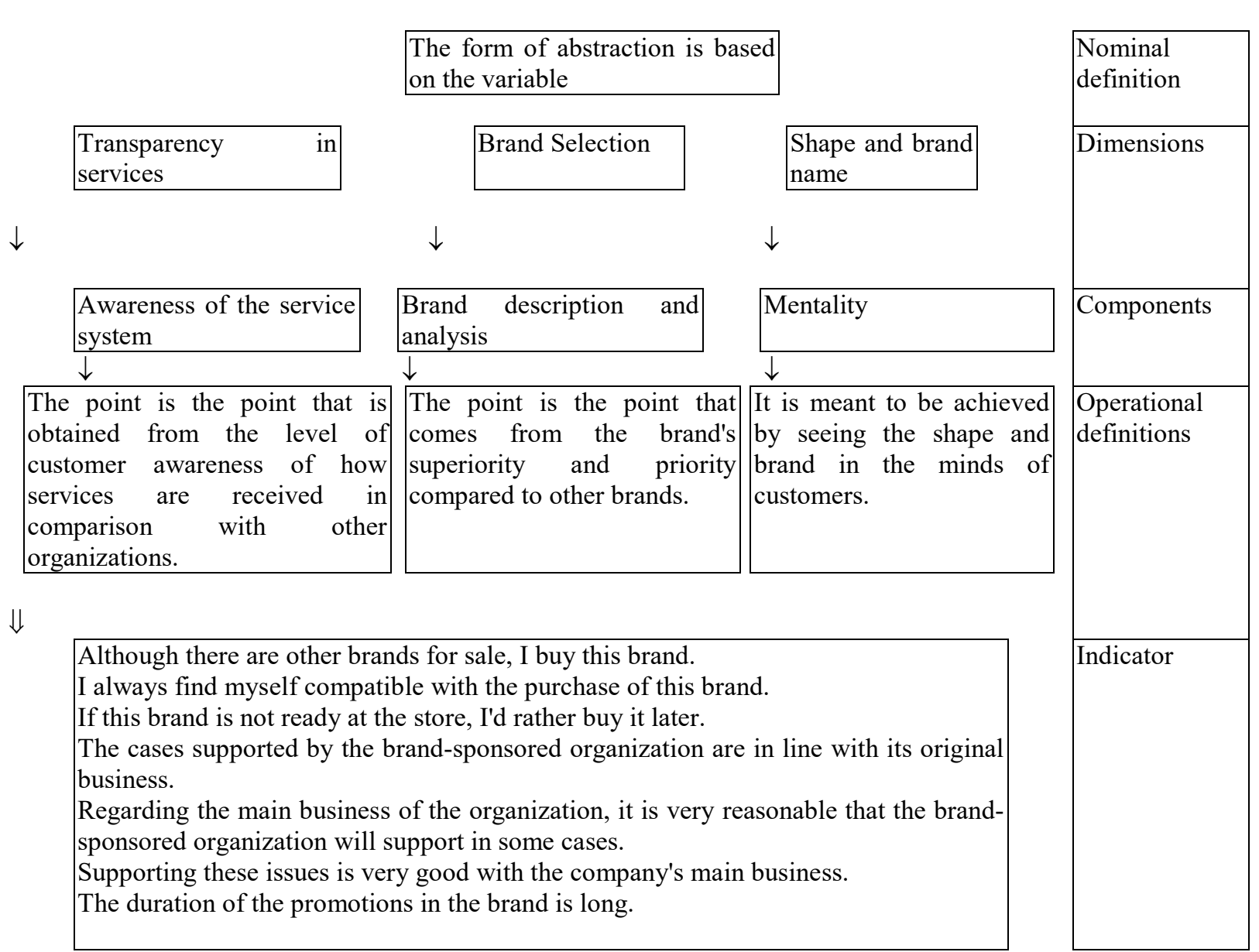

Although there are other brands for sale, I buy this brand.

I always find myself compatible with the purchase of this brand.

If this brand is not ready at the store, I'd rather buy it later.

The cases supported by the brand-sponsored organization are in line with its original business.

Regarding the main business of the organization, it is very reasonable that the brandsponsored organization will support in some cases.

Supporting these issues is very good with the company's main business.

The duration of the promotions in the brand is long.

Abstraction form based on the variable of stretching

\begin{tabular}{|l|}
\hline $\begin{array}{l}\text { Actual and practical } \\
\text { commitment } \\
\text { service }\end{array}$ \\
\hline
\end{tabular}

$\downarrow$

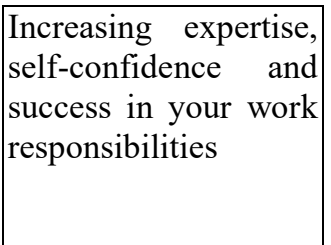

$\downarrow$ obtained from the degree of utilization and utilization of the skills necessary to carry out a job with a profession in an organization.

Transforming a good
sense of work

$\downarrow$

\begin{tabular}{|l|}
\hline $\begin{array}{l}\text { Employee } \\
\text { satisfaction, } \\
\text { constructive } \\
\text { solutions, motivation }\end{array}$ \\
$\downarrow$ \\
$\begin{array}{l}\text { The point is that the } \\
\text { change in } \\
\text { behavior the } \\
\text { employees r after } \\
\text { transferring a sense of } \\
\text { goodness from the } \\
\text { colleagues is in line } \\
\text { with the goals of the } \\
\text { organization. }\end{array}$ \\
\hline
\end{tabular}

\begin{tabular}{|lll|}
\hline $\begin{array}{l}\text { Setting up personal } \\
\text { goals }\end{array}$ & \\
\hline
\end{tabular}

\section{$\downarrow$}

Promotion of work, promotion of insight and the level of job and social awareness in the workplace and the use of acquired expertise.

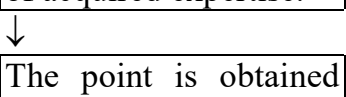
using the experience and capabilities acquired during work....
Detecting the feelings of colleagues

$\downarrow$

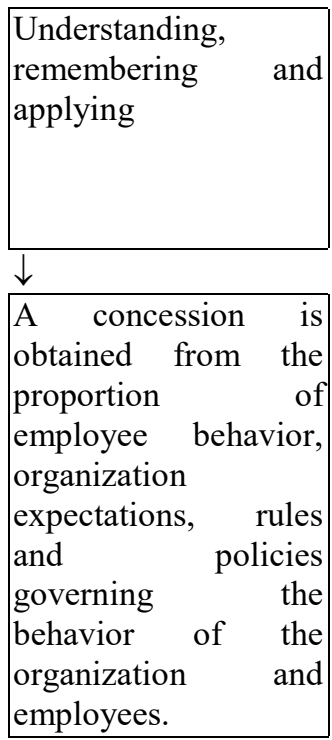

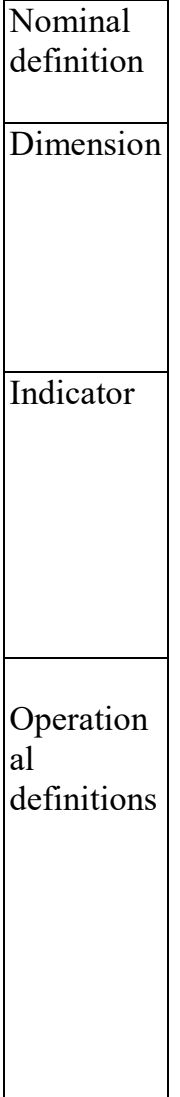


$\Downarrow$

I always feel my friends in their behavior.

I see the feelings of others very well.

I always set my goals for myself and then look for the best ways to reach them.

I always say to myself that I am a decent person.

I am a motivated person for the sake of excellence and the goals of the organization

I feel good about this because I often experience a special feeling of myself.

There is a real and practical commitment to serving the organization

Look at customers as opportunities rather than sources of revenue.

The organization's existential philosophy is due to its services to the needs of its customers.

Regular management takes care of customer service and frontline staff

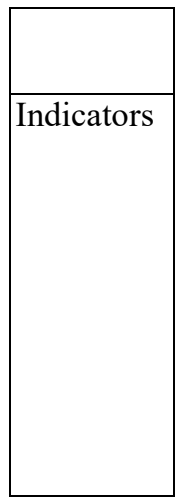

Abstraction form based on satisfaction variable

\section{Quality used by the customer}

$\downarrow$

\begin{tabular}{|lr|}
\hline Transparency, & Skills, \\
Standards & and \\
Criteria & \\
& \\
\end{tabular}

$\downarrow$ organization achieves the standards and criteria for work in providing customer service in order to learn and train employees.

Importance of needs
and interests

$\downarrow$

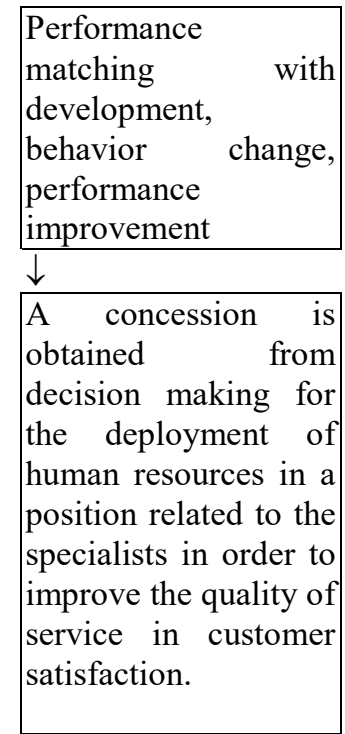

\section{Increasing the ability of} employees

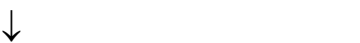

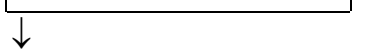

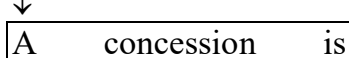

obtained using the experience capabilities during the work for customer satisfaction.

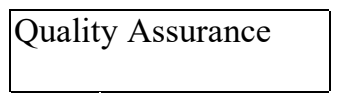

$\downarrow$

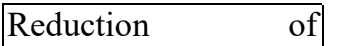

deviations, customer satisfaction, organizational development

\section{$\downarrow$}

The point is that the importance of progress,

promotion

organizational

delivery to the staff, regular monitoring and evaluation to reduce the deviations in the provision of services is achieved.

$\Downarrow$

The company delivers the expected quality of the customer

The company has a list of customer needs.

Complaints will be answered within two days and will be resolved in the same week.

In the company, customer satisfaction is one of the criteria for job performance.

The quality of service is measured continuously.

Regarding the services the company offers, the situation is constantly under special supervision. Practically provides management with a view to enhancing the staff's ability to deliver excellent resources.

Managers give input to people and lead them to create quality services.

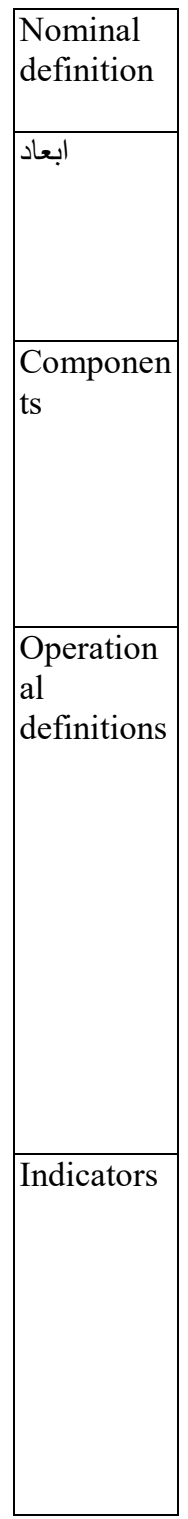




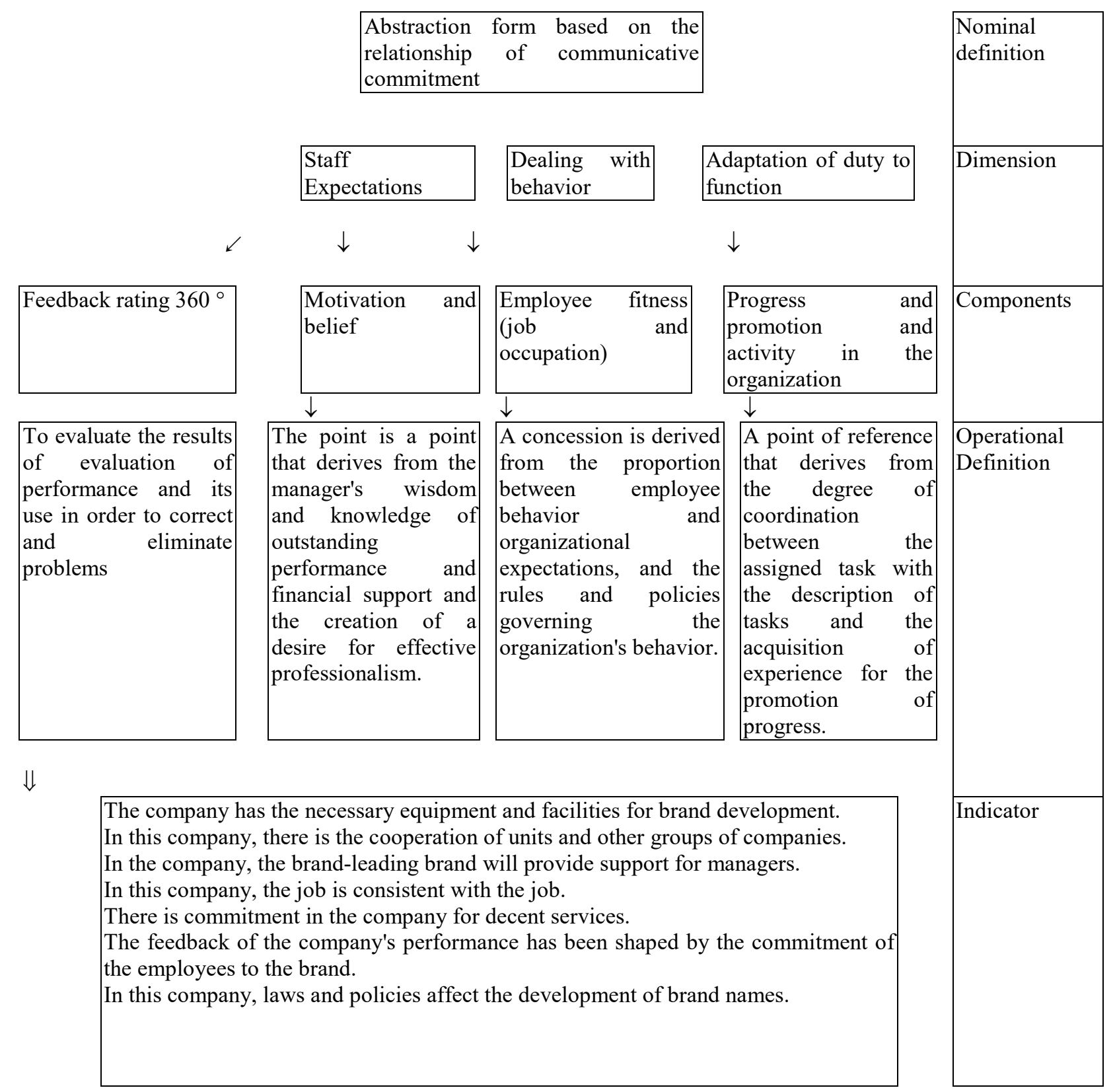




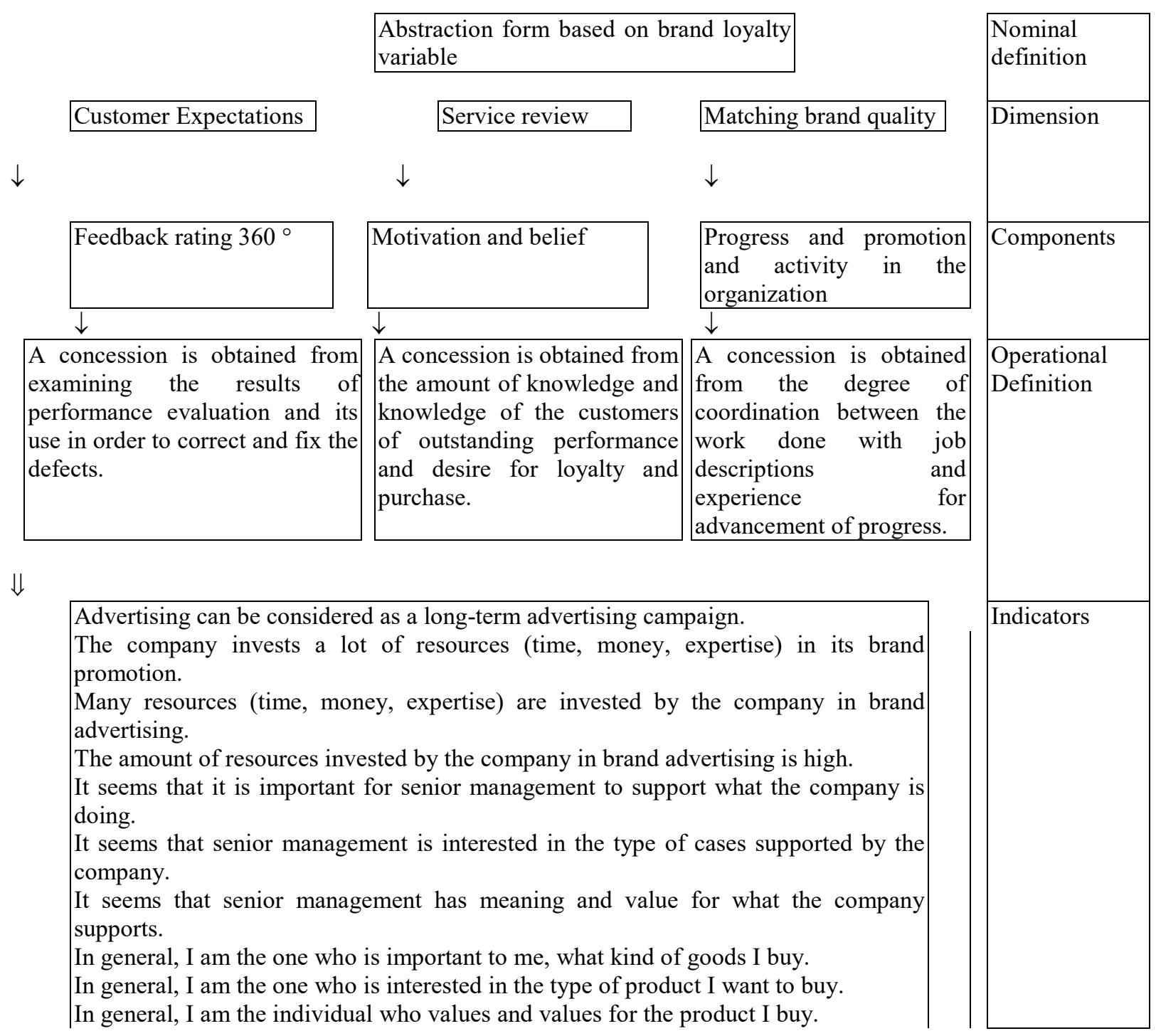

\section{Discussion and conclusion}

\subsection{Results of descriptive statistics}

The results of the research also show that the total number of 168 samples is the most frequent in women with $58.7 \%$ and the least frequent in men is $41.3 \%$. The results of this study show that from 186 individuals the sample is $32.9 \%$, that is, the highest frequency is between the ages of $30-40$ years and $11.5 \%$, the least frequent are those older than 50 years old. The results of the research also show that out of a total of 186 samples, the most sample individuals, $36.4 \%$, have undergraduate education and the least sample is $10.8 \%$ associate.

Analysis of the results of the test of the research hypotheses

This research seeks to answer the question of whether the cognitive motivators affect brand loyalty in terms of communication commitment, brand, and motivational satisfaction. To answer this question, research hypotheses have been tested and below the results of this hypothesis Have been discussed and discussed.

\section{Analysis of research hypotheses}

First hypothesis: brand awareness affects pleasure

The standard coefficient of brand awareness brand on brand pleasure is $0 / 379$, because its significance level is less than $0.05(\mathrm{P}<0.05)$ and the absolute value of the critical ratio is more than $1.96(1.96)$ this path is meaningful. Given the fact that this coefficient is positive, it can be concluded that the two variables have a direct relationship with each other that their relationship is significant. In other words, 37.9 percent of enjoyment variations are predictable by brand awareness. In other words brand awareness affects brand pleasure. Therefore, the above hypothesis is accepted. 
Second hypothesis: brand awareness has an effect on excitation.

The standard coefficient of brand awareness pathway on excitation is 0.336 . Since its significance level is less than $0.05(\mathrm{P}<0.05)$ and the absolute value of the critical ratio is more than $1.96(1.96)$, this path is meaningful. Given the fact that this coefficient is positive, it can be concluded that the two variables have a direct relationship with each other that their relationship is significant. In other words, $36.3 \%$ of changes in excitability are predictable by brand awareness. In another sense, awareness is arousing arousal. Therefore, the above hypothesis is accepted.

Third sub-hypothesis: Perceived quality affects pleasure.

The standard coefficient of perceived quality path on pleasure is 0.254 which, because its significance level is less than $0.05(\mathrm{P}<0.05)$, and the absolute value of the critical ratio is more than 1.96 (1.96). This path is meaningful. Given the fact that this coefficient is positive, it can be concluded that the two variables have a direct relationship with each other that their relationship is significant. In other words, it's possible to say that $25.4 \%$ of the pleasures are predictable by the quality of the brand. In other words brand quality affects brand pleasure. Therefore, the above hypothesis is accepted.

Sub-hypothesis 4: Perceived quality affects excitation.

The standard coefficient of quality perceived quality perception on excitability is 0.226 . Since its significance level is less than $0.05(\mathrm{P}<0.05)$ and the absolute value of the critical ratio is more than $1.96(1.96)$, this path is meaningful. Given the fact that this coefficient is positive, it can be concluded that the two variables have a direct relationship with each other that their relationship is significant. In other words, it can be said that $22.6 \%$ of changes in excitability are predictable by perceived quality. In another sense, perceived quality affects arousal. Therefore, the above hypothesis is accepted.

Fifth sub-hypothesis: Brand image affects pleasure.

The standard coefficient of the image pathway is about 155/0 that is, since its significance level is less than 0.05 $(\mathrm{P}<0.05)$ and the absolute value of the critical ratio is greater than $1.96(\mathrm{t} / 96)$, this is a significant is. Given the fact that this coefficient is positive, it can be concluded that the two variables have a direct relationship with each other that their relationship is significant. In other words, it can be said that 15.5 percent of pleasures are predictable by the brand image. In other words, brand image affects brand pleasure. Therefore, the above hypothesis is accepted.

The sixth hypothesis: Brand image has an effect on excitation.

The standard coefficient of image brand image on excitement is 0.22 which, because its meaningful level is less than $0.05(\mathrm{P}<0.05)$ and the absolute value of the critical ratio is more than $1.96(1.96)$, this path Meaningful. Given the fact that this coefficient is positive, it can be concluded that the two variables have a direct relationship with each other that their relationship is significant. In other words, it can be said that 12.2 percent of the change in excitement is predictable by the brand image. In other words, brand image affects arousal. Therefore, the above hypothesis is accepted.

\section{Seventh hypothesis: Perceived value affects pleasure.}

The value of the standard coefficient of perceived value path on pleasure is $203 / 0$, because its meaningful level is less than $0.05(\mathrm{P}<0.05)$ and the absolute value of the critical ratio is more than 1.96 (1.96) This path is meaningful. Given the fact that this coefficient is positive, it can be concluded that the two variables have a direct relationship with each other that their relationship is significant. In other words, it can be said that $20.3 \%$ of pleasure variations are predictable by the amount of perceived value. In another sense, the perceived value affects brand pleasure. Therefore, the above hypothesis is accepted.

Eighth hypothesis: Perceived value affects arousal.

The standard coefficient of the perceived value pathway on arousal is 0.151 which, because its significance level is less than $0.05(\mathrm{P}<0.05)$ and the absolute value of the critical ratio is more than $1.96(1.96)$, this path is meaningful. Given the fact that this coefficient is positive, it can be concluded that the two variables have a direct relationship with each other that their relationship is significant. In other words, it can be said that 15.1 percent of the change in excitability is predictable by the amount of perceived value. In another sense, the perceived value affects excitation. Therefore, the above hypothesis is accepted.

\section{Ninth hypothesis: Joy affects brand satisfaction.}

The standard coefficient of pleasure path on brand satisfaction is 0.232 which, because its significance level is less than $0.05(\mathrm{P}<0.05)$ and the absolute value of the critical ratio is more than $1.96(1.96)$, this path meaningful. Given the fact that this coefficient is positive, it can be concluded that the two variables have a direct relationship with each other that their relationship is significant. In other words, it can be said that 23.2 percent of changes in brand satisfaction are predictable by the amount of pleasure. In another sense, they enjoy the brand's satisfaction. Therefore, the above hypothesis is accepted.

Tentative hypothesis: Arousal affects brand satisfaction.

The standard coefficient of the path of arousal on brand satisfaction is 0.270 which, because its significance level is less than $0.05(\mathrm{P}<0.05)$ and the absolute value of the critical ratio is more than $1.96(1.96)$, this The path is 
meaningful. Given the fact that this coefficient is positive, it can be concluded that the two variables have a direct relationship with each other that their relationship is significant. In other words, it can be said that 27 percent of changes in brand satisfaction are predicted by the amount of arousal. In another sense, arousal affects brand satisfaction. Therefore, the above hypothesis is accepted.

\section{Elementary Hypothesis 11: Brand Satisfaction Affects Communication Commitment.}

The standard coefficient of brand satisfaction path is 2.052 which, because its significance level is less than 0.05 $(\mathrm{P}<0.05)$, and the absolute value of the critical ratio is more than $1.96(1.96)$, this The path is meaningful. Given the fact that this coefficient is positive, it can be concluded that the two variables have a direct relationship with each other that their relationship is significant. In other words, it can be said that $20.2 \%$ of the communication commitment changes are predictable by brand satisfaction. In other words, brand satisfaction affects communication commitment. Therefore, the above hypothesis is accepted.

12th hypothesis: brand satisfaction affects brand loyalty.

The standard coefficient of brand satisfaction mark on brand loyalty is $360 / 0$ which, because its significance level is less than $0.05(\mathrm{P}<0.05)$, and the absolute value of the critical ratio is more than $1.96(1.96)$ This path is meaningful. Given the fact that this coefficient is positive, it can be concluded that the two variables have a direct relationship with each other that their relationship is significant. In other words, it can be said that $36 \%$ of brand loyalty changes are predictable by brand satisfaction. In other words, brand satisfaction affects brand loyalty. Therefore, the above hypothesis is accepted.

Thirteenth hypothesis: Communicative Commitment affects brand loyalty.

The ratio of the standard coefficient of affiliation to brand loyalty is $349 / 0$ which, because its significance level is less than $0.05(\mathrm{P}<0.05)$ and the absolute value of the critical ratio is more than $1.96(1.96)$, this path Meaningful. Given the fact that this coefficient is positive, it can be concluded that the two variables have a direct relationship with each other that their relationship is significant. In other words, $34.9 \%$ of brand loyalty changes can be predicted by the amount of communication commitment. In other words, communication commitment affects brand loyalty. Therefore, the above hypothesis is accepted.

Comparing the results of the research with previous researches

Table (1-5): Comparison of previous research or current research

\begin{tabular}{|c|c|c|c|c|c|}
\hline Result & Conclusion & Subject & Year & Researcher & Column \\
\hline Confirmed & $\begin{array}{l}\text { there is a direct relationship. Also, } \\
\text { there is a meaningful relationship } \\
\text { between information resources } \\
\text { and product involvement. With } \\
\text { the smallest increase in product } \\
\text { orientation, brand commitment is } \\
\text { significantly growing, meaning } \\
\text { brand commitment is heavily } \\
\text {.dependent on product orientation }\end{array}$ & $\begin{array}{l}\text { Investigating the } \\
\text { relationship between } \\
\text { product involvement } \\
\text { and } \quad \text { brand } \\
\\
\text { commitment }\end{array}$ & 2018 & $\begin{array}{r}\text { Abdulvand } \\
\text { and } \\
\text { Collogues }\end{array}$ & 1 \\
\hline Confirmed & $\begin{array}{l}\text { Brand trust plays a key role in } \\
\text { improving customer behavioral } \\
\text { habits. Also, increasing } \\
\text { continuous customer commitment } \\
\text {.reduces their willingness to brand }\end{array}$ & \begin{tabular}{lr} 
A Model & for \\
Assessing the Effect \\
of Bank Brand Trust \\
on \\
Commitment $r$ of \\
\multicolumn{2}{r}{ Customers }
\end{tabular} & 2017 & $\begin{array}{r}\text { Dehdashti } \\
\text { Shahrokh } \\
\text { and } \\
\text { colleagues }\end{array}$ & 2 \\
\hline Confirmed & $\begin{array}{l}\text { Among the dimensions of brand } \\
\text { personality, only the dimensional } \\
\text { dimension of brand personality } \\
\text { affects behavioral loyalty. } \\
\text { Therefore, it is better to examine } \\
\text { attitudinal and behavioral } \\
\text { allegiance in examining the effect } \\
\text {.of brand personality }\end{array}$ & \begin{tabular}{l} 
Evaluation of the \\
effect of brand \\
personality \\
attitude on \\
behavioral loyalty of \\
customers and \\
\multicolumn{2}{c}{ Hyperstar brand }
\end{tabular} & 2016 & $\begin{array}{r}\text { Goodarzi } \\
\text { and } \\
\text { colleagues }\end{array}$ & 3 \\
\hline Contradicted & $\begin{array}{l}\text { The consistency of brand and } \\
\text { customer personality traits can } \\
\text { create a customer's trust and sense } \\
\text { of belonging to the brand, which } \\
\text { leads to repeat purchases, in other } \\
\text { words, customer loyalty to the } \\
\text { brand and, ultimately, the creation } \\
\text {.of brand equity }\end{array}$ & $\begin{array}{l}\text { Investigating the } \\
\text { relationship between } \\
\text { brand equity with } \\
\text { brand and customer } \\
\text { personality } \\
\text { consistency }\end{array}$ & 2015 & $\begin{array}{r}\text { Azizi and } \\
\text { colleagues }\end{array}$ & 4 \\
\hline
\end{tabular}




\begin{tabular}{|c|c|c|c|c|c|}
\hline Result & Conclusion & Subject & Year & Researcher & Column \\
\hline Contradicted & $\begin{array}{l}\text { Experiences and attitudes of } \\
\text { consumers affect the formation of } \\
\text { affective affiliation with brand. } \\
\text { Also, consumers who depend on } \\
\text { the brand have higher levels of } \\
\text { loyalty, oral word-of-mouth } \\
\text { releases, and tend to pay higher } \\
\text {.prices for the brand }\end{array}$ & $\begin{array}{l}\text { Investigating the } \\
\text { affective affection of } \\
\text { consumers towards } \\
\text { the brand, taking into } \\
\text { account pre-requisites } \\
\text { and outcomes }\end{array}$ & 2015 & $\begin{array}{r}\text { Kheyri and } \\
\text { colleagues }\end{array}$ & 5 \\
\hline Confirmed & $\begin{array}{l}\text { Evaluation of the effect of brand } \\
\text { mediation between personality } \\
\text { and brand attitude with brand } \\
\text { equity. To test the model, a } \\
\text { sample of } 432 \text { people was } \\
\text { selected through a cluster } \\
\text { sampling method from among the } \\
\text { customers of large chocolate } \\
\text {.stores in Iran }\end{array}$ & $\begin{array}{l}\text { Evaluation of the } \\
\text { effect of brand image } \\
\text { mediation on brand } \\
\text { value formation }\end{array}$ & 2018 & $\begin{array}{r}\text { Emari and } \\
\text { colleagues }\end{array}$ & 6 \\
\hline Contradicted & $\begin{array}{l}\text { Overall level, brand personality } \\
\text { dimensions on equity, positive } \\
\text { effect and attractiveness of } \\
\text { consumer promotion have a } \\
\text { negative effect. The positive } \\
\text { effect of brand personality is } \\
\text { more than its negative effect on } \\
\text {.sales promotion }\end{array}$ & $\begin{array}{l}\text { Investigating the } \\
\text { effect of brand } \\
\text { personality and sales } \\
\text { promotion on brand } \\
\\
\text { equity }\end{array}$ & 2017 & $\begin{array}{r}\text { Volt } \\
\text { Florence and } \\
\text { colleagues }\end{array}$ & 7 \\
\hline Confirmed & $\begin{array}{l}\text { Brand experience has a positive } \\
\text { effect on brand satisfaction, brand } \\
\text { trust and brand loyalty, and brand } \\
\text { trust and satisfaction have a } \\
\text { positive and significant effect on } \\
\text {.brand loyalty }\end{array}$ & $\begin{array}{l}\text { Investigating the } \\
\text { effect of brand } \\
\text { experiences, trust and } \\
\text { satisfaction on brand } \\
\text { loyalty }\end{array}$ & 2016 & $\begin{array}{r}\text { Shahin and } \\
\text { colleagues }\end{array}$ & 8 \\
\hline Confirmed & $\begin{array}{l}\text { Hotels belonging to the same } \\
\text { category have different brand } \\
\text { equity, and brand differentiation } \\
\text { and brand trust are variables that } \\
\text { have a great influence on } \\
\text {.customer business relationships }\end{array}$ & $\begin{array}{l}\text { Investigating the } \\
\text { Relationship between } \\
\text { Equal Rights and } \\
\text { Brand Commitment }\end{array}$ & 2015 & $\begin{array}{r}\text { Kim } \\
\text { Paquren and } \\
\text { colleagues }\end{array}$ & 9 \\
\hline Confirmed & $\begin{array}{l}\text { Consumers' satisfaction plays a } \\
\text { modest mediator role between } \\
\text { employee behavior, the concept } \\
\text { of brand identity and brand } \\
\text { loyalty, and the overall mediator } \\
\text { role between physical quality and } \\
\text { the integrity of lifestyle with } \\
\text {.brand loyalty }\end{array}$ & $\begin{array}{l}\text { Investigating the } \\
\text { relationship between } \\
\text { brand equity, brand } \\
\text { loyalty and consumer } \\
\text { satisfaction }\end{array}$ & 2014 & $\begin{array}{r}\text { Tom and } \\
\text { colleagues }\end{array}$ & 10 \\
\hline
\end{tabular}

\subsection{Discussion and Conclusion}

Nowadays, having a strong brand is one of the priorities of many organizations, so researchers in this field have always looked at it in different aspects, because brand status can be done both internally and externally. The branding approach outside the organization is a topic that has hitherto been the focal point of countless researchers and, of course, targeting customers, thus choosing ways to directly relate to the customer; on the other hand, employees are the most influential factors in the formation of the organization brand is in the minds of consumers and consumers of goods and services; in this case, the domestic brand is said to promote the brand within the organization, that is, the same employees, and on the other hand, the undeniable role of the employees has led to the human resources to build the brand in recent years, The focus of many scientific research. The study of the literature on the subject clearly shows that very little studies have been conducted on internal branding (based on human resources), and few studies have addressed this issue. In particular, by studying in domestic research sources, it is safe to say that research on the effect of brand-based human resource 
management has not been conducted on other structural variables, so understanding the importance of the brandbased brand in the organization and its role in creating and Brand promotion In this research, four important variables of marketing in the form of cognitive motivators in the conceptual model were used. Using the relationship between variables, the hypothesis test was performed. Based on the obtained results, all the trajectories traced in the research model are known. And their causal relationship at the level of confidence $95 \%$ was accepted. In general, the results showed that the dimensions of brand cognitive motivations in a company could lead to customer satisfaction and brand loyalty, which points to the importance of interaction between marketing and personnel departments in the company. Managers of the organization can, while reviewing the articles of association of the company and the organizational structure, help strengthen the engagement in order to increase the appropriate citizenship behavior. On the other hand, the results of the research confirmed that appropriate citizenship behavior at the organizational level and strengthening its dimensions could lead to customer satisfaction, and this should be considered with a general view along with other variables of research. Increasing interaction between human resources management and marketing sectors in order to strengthen the brand can lead to customer satisfaction with products and services. In this research, we also confirmed some of the above mentioned suggestions in this field. In addition, this research presented a theoretical model that marketing researchers can use to obtain the results and compare them with the results of other research that can be found in the field of service marketing, can provide strong theoretical support for variables and provide a solution. In order to increase customer satisfaction by focusing on the role of human resources at the individual and organizational level and strengthening brand loyalty, this issue is found less in literature and research background.

\section{References}

Heidarzadeh, Kambiz; Elwani, Seyyed Mahdi and Qalandari, Kamal. (1394). "The effect of brand credibility on customer loyalty in the banking industry of Iran". Management Research, No. 86, pp. 72-95.

Khanifar, Hossein, Moghimi, Seyyed Mohammad, Jandaghi, Gholamreza and Zorandi, Nafisa. (1393). "Investigating the Relationship between Components of Trust and Organizational Commitment of Employees (in Agricultural Jihad and Education Institutions of Qom Province)". Governmental Management, Volume 1, Issue 2, pp. 18-6.

Khairi, Bahram; Samii Nasr, Mahmoud; Azimpoor Khojin, Mohammad. (1394). "Investigating consumers' affective affiliation with brand, taking into account preconditions and results". Marketing Management, No. 20 , pp. 65-52.

Dehdashti Shahrokh, Zohreh; Jafarzadeh Kanari, Mehdi; Shafiezadeh, Alireza. (1396). "A Model for Assessing the Effect of Bank Brand Trust on Customer Loyalty Commitment". Journal of Research in New Marketing Research, No. 2, Issue 5, pp. 106-88.

Rahimnia, Fariborz; Fatemi, Seyed Zahra. (1395). "Investigating the role of customer value-based intermediary brand equity in the impact of successful customer relationship and brand image in five star hotels in Mashhad", Journal of Research in New Marketing Research, Second Year, No. 1, Issue 4, pp. 27- 53. .

Rashidi, Hassan; Rahmani, Zain al-Abedin. (1396). "Brand and its impact on customer loyalty". Economics Magazine No. 9 and 10, pp. 84- 105.

Rezaeian, Reza (1395). "The Effect of Social Responsibility of the Organization on Perception (Organizational Trust and Job Satisfaction) of the Social Security Staff of Bandar Abbas City", Third National Millennium Conference and Humanities, Shiraz, Center for the Development of Modern Education in Iran (Metana). P. 9-25.

Ranjbarian, Bahram; Barari, Mojtaba. (1396). "The Effect of Affiliated Marketing Foundations on Customer Loyalty: A Comparison Between Public and Private Banking". Commercial Management, Volume 1, Issue 2, pp. 100-87.

Safarzadeh, Hossein, Khairi, Bahram; Agha Seyyed Agha. Reyhanah (1395). "The study of the effect of background factors, brand loyalty and brand change on the decision to purchase young consumers." Marketing Management, No. 10, pp. 94-65.

Abdulwand, Mohammad Ali; Nikfar, Fatemeh (1397). "The study of the relationship between product conflict and brand commitment." Marketing Management, No. 13, pp. 94-75.

Cronin, J. J., Brady, M. K., \& Hult, G.T. (2017). Assessing the Effects of Quality, Value, and Customer Satisfaction on Consumer Behavioral Intentions in Service Environments. Journal of Retailing, 76(11), 122154.

Deck, T. \& Bas, T. (2014). "Does experience matter? Differences in relationship benefits, satisfaction, trust, commitment and loyalty for novice and experienced service users", Journal of Marketing, 44 (9), pp. 25-36.

Dimitriades Z. (2017). "Customer satisfaction, loyalty and commitment in service organizations some evidence from Greece", Journal of Management Research, 29 (12), pp.72-100.

Duffy, D. (2010). "The evolution of customer loyalty strategy", Journal of Consumer Marketing, 22 (5), pp. 284 


$$
-286 .
$$

Finn, A. (2015). "Investigating the non-linear effects of e-service quality dimensions on customer satisfaction", Journal of Retailing and Consumer Services, 18 (1), pp. 37-66.

Freling, T. H. and Forbes, L. P. (2010). An empirical analysis of the brand personality effect. Journal of Product and Brand Management. 14(7), 404-413.

Fullerton, G. (2018). "Creating advocates: The role sofsatisfaction, trust and commitment", Journal of Retailingand Consumer Services, 18 (1), pp. 114-129.

Geuens Maggie, Weijters Bert, De Wulf Kristof (2018). A new measure of brand personality. International Journal of Research in Marketing, Vol 26, P P 97-107.

Ghodeswar, B. M. (2017). Building brand identity in competitive markets: a conceptual model, Journal of Product \& Brand Management, 17(1), 35-66.

Gilbert.and veloutsou and goode and moutinho (2014).measuring customer satisfaction in the fast food industry. Journal of service marketing 'vol.18 NO. 5. pp 371-383.

Hamington, M., Kuivalainen, O., Tarkiainen, A., Ellonen, H., (2018). Online satisfaction, trust and loyalty, and the impact of the offline parent brand. Journal of Product \& Brand Management 17(3), 60- 76.

Han, H., Ryu, K., (2012). The theory of repurchase decision-making (TRD): ientifying the critical factors in the postpurchase decision-making process. Int. J. Hospitality Manage. 31, 4-25.

Han, X., Kwortnik, R.J., Wang, C., (2018). Drivers in the coffee chain chain. J. Serv. Res. 11 (1), 5-20.

He , H. Li, Y. \& Harris, L. (2011). Social identity perspective on brand loyalty. Journal of Business Research, doi:10.1016/j.jbusres.03.007.

Homburg, C., Klarmann, M., Schmitt, J., (2018). Brand awareness in business markets: when is it related to firm performance? Int. J. Res. Market. 27 (3), 54-67.

Ishak, P.M., MacKenzie, S.B., Lee, J.Y., Podsakoff, N.P., (2013). Common methodbiases in behavioral research: a critical review of the literature and recommended remedies. Journal of Applied Psychology 88 (5), 42-57.

Kapferer J-N.(2015). The new strategic brand management, creating and sustaining brand equity long term.London: Kogan Page.36-54

Kater, J., Ekinci, Y., Whyatt, G., (2016). Brand equity, brand loyalty and consumer satisfaction. Ann. Tour. Res. $38(3), 81-115$.

Keller, K. L. (2017), "Strategic Brand Management-Building, Measurig, and Managing Brand Equity (3rd ed.,)",United States: PEARSON - Prentice Hall. Pp: 160-172

Kifer, D. A. (2010). Intra-brand equity value and its relation to brand equity on the basis of customers in the market and insurance companies. New York: The Free Press .13(5), 25-36. 